\title{
ANALISIS AKTIVITAS ANTIOKSIDAN, KANDUNGAN ZAT GIZI MAKRO DAN MIKRO SNACK BAR BERAS WARNA SEBAGAI MAKANAN SELINGAN PENDERITA NEFROPATI DIABETIK
}

\author{
Verina Permatasari Hakim, Fitriyono Ayustaningwarno ${ }^{*}$ \\ Program Studi Ilmu Gizi Fakultas Kedokteran Universitas Diponegoro \\ J1.Dr.Sutomo No.18, Semarang, Telp (024) 8453708, Email : gizifk@ undip.ac.id
}

\begin{abstract}
Background: Diabetic nephropathy is one of the microvascular complications of chronic hyperglycemia due to diabetes mellitus patients. Strategies that can be done to reduce the risk or to slow down of diabetic nephropathy are by doing proper management of diet to maintain optimal nutritional status, controlling blood glucose, blood lipids, blood pressure, intake of protein and antioxidants, as well as to maintain electrolyte balance. Modification of a snack bar variation using processed rice product of colored rice and materials such as inulin and isomalt binder can produce attractive products with better nutritional content.

Objective: To analyze the antioxidant activity, macro and micro nutrients content of colored rice snack bar, with the result is colored rice snack bar serving standard that can be recommended as a snack for patients with diabetic nephropathy.

Methods: The completely randomized single factor experimental design which is used 3 color rice processed products include puffed rice brown rice, red and black. Fat, antioxidant activity, potassium and phosphorus analyzed by Tukey test.

Results: The nutrient content of brown rice snack bar formulation for each $40 \mathrm{~g}$ serving size is $160.39 \mathrm{kcal}$ energy, $2.78 \mathrm{~g}$ protein, $1.42 \mathrm{~g}$ fat, $34.04 \mathrm{~g}$ carbohydrates, 14,27 \% antioxidant activity, $46.82 \mathrm{mg}$ potassium, $25.69 \mathrm{sodium}$, and $0.16 \mathrm{mg}$ phosphorus. The nutrient content red rice snack bar formulation for each $40 \mathrm{~g}$ serving size is 158.47 kcal energy, $2.53 \mathrm{~g}$ protein, $1.51 \mathrm{~g}$ fat, $33.68 \mathrm{~g}$ carbohydrates, 14,72\% antioxidant activity, $34.44 \mathrm{mg}$ potassium, $19.33 \mathrm{mg}$ sodium, and $0.11 \mathrm{mg}$ phosphorus. The nutrient content black rice snack bar formulation for each $40 \mathrm{~g}$ serving size is $157.14 \mathrm{kcal}$ energy, $2.63 \mathrm{~g}$ protein, $1.30 \mathrm{~g}$ fat, $33.73 \mathrm{~g}$ carbohydrates, 25,52\% antioxidant activity, $47.46 \mathrm{mg}$ potassium, $23.90 \mathrm{mg}$ sodium, and $0.19 \mathrm{mg}$ phosphorus.

Conclusion: All of colored rice snack bar has low protein and fat content, but higher carbohydrate content compared with the calculated nutrient content of snack for diabetic nephropathy patients. Antioxidant activity of black rice snack bar (25,52\% for each $100 \mathrm{~g}$ snack bar) is the highest compared with the third snack bar. Recommended snack bar is black rice snack bar.
\end{abstract}

Keywords: Diabetic nephropathy; macro and micro nutrient content; colored rice snack bar

\begin{abstract}
ABSTRAK
Latar Belakang: Nefropati diabetik merupakan salah satu komplikasi mikrovaskuler akibat hiperglikemi yang bersifat kronis pada pasiaen diabetes mellitus. Strategi yang dapat dilakukan untuk menurunkan risiko atau memperlambat progresifitas nefropati diabetik adalah dengan melakukan penatalaksanaan diet yang tepat untuk mempertahankan status gizi optimal, mengendalikan glukosa darah, lipida darah, tekanan darah, asupan protein dan antioksidan, serta mempertahankan keseimbangan elektrolit. Modifikasi makanan selingan berupa snack bar menggunakan produk olahan beras warna serta bahan pengikat berupa inulin dan isomalt dapat menghasilkan produk yang menarik dengan kandungan zat gizi lebih baik.

Tujuan: Menganalisis aktivitas antioksidan, kandungan zat gizi makro dan mikro snack bar beras warna, sehingga dapat diperoleh standar porsi snack bar beras warna yang dapat direkomendasikan sebagai makanan selingan penderita nefropati diabetik.

Metode: Penelitian eksperimental acak lengkap 1 faktor yaitu 3 produk olahan beras warna meliputi brondong beras coklat, merah dan hitam. Data kandungan lemak, antioksidan, kalium dan fosfor, dianalisis dengan uji Tukey. Hasil: Kandungan zat gizi pada formulasi snack bar beras coklat dengan takaran saji $40 \mathrm{~g}$ adalah 160,39 kkal energi, 2,78 g protein, 1,42 g lemak, 34,04 g karbohidrat, 14,27 \% aktivitas antioksidan, 46,82 mg kalium, 25,69 natrium, dan 0,16 mg fosfor. Kandungan zat gizi pada formulasi snack bar beras merah dengaan takaran saji $40 \mathrm{~g}$ adalah 158,47 kkal energi, 2,53 g protein, 1,51 g lemak, 33,68 g karbohidrat, 14,72\% aktivitas antioksidan, 34,44 mg kalium, 19,33 mg natrium, dan 0,11 mg fosfor. Kandungan zat gizi pada formulasi snack bar beras hitam dengan takaran saji $40 \mathrm{~g}$ adalah 157,14 kkal energi, 2,63 g protein, 1,30 g lemak, 33,73 g karbohidrat, 25,52 \% aktivitas antioksidan, 47,46 $\mathrm{mg}$ kalium, 23,90 $\mathrm{mg}$ natrium, dan 0,19 $\mathrm{mg}$ fosfor.

Kesimpulan: Semua snack bar beras warna memiliki kandungan protein dan lemak yang rendah namun kandungan karbohidrat lebih tinggi jika dibandingkan dengan hasil perhitungan kandungan zat gizi makanan selingan
\end{abstract}

${ }^{*}$ Penulis Penanggungjawab 
penderita nefropati diabetik. Snack bar beras hitam memiliki aktivitas antioksidan (25,52\% per $100 \mathrm{~g}$ snack bar) yang paling tinggi diantara ketiga jenis snack bar. Snack bar yang direkomendasikan adalah snack bar beras hitam. Kata kunci : nefropati diabetik; kandungan gizi makro dan mikro; snack bar beras berwarna

\section{PENDAHULUAN}

Nefropati diabetik merupakan salah satu komplikasi mikrovaskuler akibat hiperglikemi yang bersifat kronis pada pasien diabetes mellitus. Nefropati diabetk ditandai dengan adanya albumin dalam urin atau microalbuminuria (30-299 mg/24 jam) dan terjadi penurunan laju filtrasi glomerulus (LFG), yaitu 90-130 ml/menit pada stadium I. Pasien nefropati diabetik yang dapat berkembang menjadi penyakit ginjal stadium akhir adalah $40 \%$ dari seluruh pasien. ${ }^{1}$

Keadaan hiperglikemi pada penderita diabetes mellitus menyebabkan stress oksidatif yaitu terjadi peningkatan pembentukan radikal bebas dan penurunan antioksidan ( $\alpha$-tokoferol, karoten, vitamin C). Radikal bebas merupakan molekul reaktif dan dapat bereaksi dengan protein, asam nukleat serta lipid, mengubah strukturnya dan menimbulkan kerusakan sel serta menyebabkan komplikasi berbagai organ salah satunya ginjal. ${ }^{2}$

Strategi yang dapat dilakukan untuk menurunkan risiko atau memperlambat progresifitas nefropati diabetik adalah dengan melakukan penatalaksanaan diet yang tepat untuk mempertahankan status gizi optimal, mengendalikan glukosa darah, lipida darah, tekanan darah, dan asupan protein, serta mempertahankan keseimbangan elektrolit. ${ }^{3}$ Selain itu untuk mengurangi efek radikal bebas pada penderita nefropati diabetik diperlukan asupan antioksidan seperti senyawa fenolik yang berfungsi sebagai antioksidan. ${ }^{4}$ Asupan protein dalam penatalaksaan diet penderita nefropati diabetik perlu diperhatikan. Pembatasan asupan protein perlu dilakukan berkaitan dengan penurunan fungsi ginjal pada penderita nefropati diabetik. Asupan protein yang dianjurkan untuk pasien nefropati diabetik adalah $0,8 \mathrm{~g} / \mathrm{kg} \mathrm{BB} / \mathrm{hari}$ ${ }^{5,6}$ Penurunan progresifitas kerusakan ginjal pada pasien nefropati diabetik berkaitan dengan asupan protein yang bernilai biologi tinggi. ${ }^{7}$

Konsumsi makanan dengan nilai biologis protein tinggi dapat meningkatkan efisiensi penyerapan dan penggunaan nitrogen serta asam amino dalam metabolisme tubuh, sehingga dapat mengurangi sisa hasil metabolisme protein yang berisiko menurunkan fungsi ginjal. ${ }^{8}$ Nilai biologis protein beras adalah 56, lebih tinggi dibandingkan dengan serealia lain namun nilai ini lebih rendah dibandingkan dengan sumber protein hewani, seperti daging, telur dan susu. ${ }^{9}$ Beras termasuk sumber energi tinggi dengan kandungan $357 \mathrm{kkal}$ energi, $8,4 \mathrm{~g}$ protein dan $1,7 \mathrm{~g}$ lemak. Pemenuhan energi sesuai kebutuhan dari sumber karbohidrat dan lemak dapat membantu mencegah katabolisme protein menjadi energi sehingga mengurangi sisa hasil metabolisme protein dan meningkatkan efisiensi penggunaan protein untuk pembentukan dan perbaikan jaringan tubuh. ${ }^{10,11}$

Beras warna memiliki kandungan senyawa fenolik yaitu antosianin. Antosianin termasuk kelompok flavonoid yang berfungsi sebagai antioksidan dan dapat menurunkan kadar glukosa darah. Hal ini didukung oleh hasil penelitian yang menyebutkan bahwa antioksidan dapat mengendalikan kadar glukosa darah dan mencegah komplikasi diabetes mellitus. ${ }^{12}$ Penelitian menyebutkan bahwa konsumsi $686 \mathrm{mg}$ antosianin dapat menurunkan glukosa darah dan meningkatkan sekresi serta sensitifitas insulin. ${ }^{13}$ Konsumsi antosianin juga berkaitan dengan penurunan risiko diabetes tipe $2 .{ }^{14}$ Kandungan antosianin , fenolik dan aktivitas antioksidan beras coklat berkisar 979-11,13 mg/100 g, 58,89-80,44 mg GAE (Gallic Acid Equivalent)/100 g, dan 10,013,1 TE (Trolox Equivalent)/100 g. Kandungan antosianin, fenolik dan aktivitas antioksidan beras merah berkisar antara 15,14-16,69 mg/100 g, 82,01-84,43 mg GAE/100 g, dan 119,9-312,3 TE/100 g. Kandungan antosianin, fenolik dan aktivitas antioksidan beras hitam berkisar 114,77 $245,36 \mathrm{mg} / 100 \mathrm{~g}, 208,42-329,24 \mathrm{mg}$ GAE/100 g dan 56,3-345,3 TE/100 g. ${ }^{15}$

Asupan natrium dan fosfor pada penderita nefropati diabetik perlu diperhatikan karena asupan natrium dan fosfor yang tinggi berkaitan dengan peningkatan hiperfiltrasi pada ginjal yang dapat menyebabkan penurunan fungsi ginjal. Anjuran asupan garam natrium $(\mathrm{Na})$ pasien nefropati diabetik maksimal $2.300 \mathrm{mg} /$ hari sesuai dengan tekanan darah, ada atau tidak edema atau asites, serta pengeluaran urin sehari. Anjuran asupan kalium lebih dari $4.000 \mathrm{mg} / \mathrm{hari}$. Anjuran asupan fosfor berkisar $1.700 \mathrm{mg}$ per /hari untuk menghindari terjadinya hiperfosfatemia (kadar fosfat dalam darah $>6 \mathrm{mg} / \mathrm{dl}) .{ }^{16}$ 
Olahan makanan yang saat ini banyak dikembangkan adalah berbasis beras yang diolah dalam beragam bentuk, salah satunya adalah brondong beras. Brondong beras tersebut diolah dengan pemanasan pada suhu dan tekanan tinggi sehingga volume biji bertambah, tekstur mengembang serta renyah. Hal ini memenuhi karakteristik bentuk bahan yang kompak, renyah, dan menarik untuk dimodifikasi menjadi olahan snack bar. ${ }^{17,18}$

Snack bar merupakan makanan ringan berbentuk batang yang bisa dikonsumsi sebagai makanan selingan. Pemberian makanan selingan umumnya dalam porsi kecil dengan kandungan zat gizi berkisar $10 \%$ dari kebutuhan energi sehari. Produksi snack bar sebagai makanan selingan untuk penderita penyakit kronik sudah dikembangkan di luar negeri, namun di Indonesia masih terbatas. ${ }^{19}$ Snack bar yang dikembangkan bertujuan untuk memenuhi kebutuhan zat gizi pada penderita nefropati diabetik yang diperoleh dari makanan selingan. Peneliti tertarik mengembangkan snack bar untuk penderita nefropati diabetik, karena bahan penyusun snack bar mudah diolah dan dimodifikasi. Sementara itu, produksi snack bar untuk pasien nefropati diabetik di Indonesia belum dikembangkan sehingga masih dibutuhkan untuk pengembangan formula snack bar sebagai alternatif makanan selingan. Berdasarkan latar belakang tersebut, maka dilakukan penelitian untuk menganalisis kandungan zat gizi makro dan mikro snack bar beras warna, sehingga dapat diperoleh takaran saji snack bar beras warna yang dapat direkomendasikan sebagai makanan selingan penderita nefropati diabetik.

\section{METODA}

Penelitian yang dilakukan termasuk dalam bidang food production. Analisis kandungan protein, lemak, karbohodrat, natrium, fosfor, aktivitas antioksidan, pada snack bar brondong beras dari variasi jenis beras warna dilaksanakan di Pusat Studi Pangan dan Gizi Universitas Gadjah Mada Yogyakarta. Analisis tingkat kesukaan pada snack bar brondong beras dari variasi jenis beras warna dilakukan di Progam Studi Ilmu Gizi Fakultas Kedokteran Universitas Diponegoro Semarang. Penyusunan proposal dilakukan pada bulan Maret sampai April 2013. Pengambilan dan analisis data serta penyusunan artikel dilakukan pada bulan Mei sampai Juli 2013.
Penelitian ini merupakan penelitian eksperimental dengan rancangan acak lengkap satu faktor yaitu tiga jenis beras warna yang diolah menjadi brondong sebagai bahan utama snack bar, meliputi (1) brondong beras coklat (2) brondong beras merah (3) brondong beras hitam. Penelitian ini didahului dengan perlakuan berupa pembuatan brondong dari variasi jenis beras warna (coklat, merah, dan hitam). Perbandingan bahan pengikat dan pengisi adalah $1,2: 1 ; 1: 1 ; 1: 1,2$. Penetapan kandungan zat gizi makanan selingan penderita nefropati diabetik berdasarkan perhitungan $10 \%$ dari kebutuhan zat gizi dalam sehari diperoleh hasil yang meliputi, $200 \mathrm{kkal}$ energi, $5 \mathrm{~g}$ protein, 6,7 g lemak, $30 \mathrm{~g}$ karbohidrat, $230 \mathrm{mg}$ natrium, $400 \mathrm{mg}$ kalium, dan $170 \mathrm{mg}$ fosfor. Penetapan persentase penambahan inulin, isomalt, minyak kelapa dan CMC dapat dilihat pada Lampiran 1. Kemudian persentase tersebut diuji coba pada brondong beras coklat untuk mengetahui jumlah bahan pengikat yang dibutuhkan untuk membentuk snack bar yang kompak. Apabila persentase tersebut dapat mengikat brondong beras coklat, maka brondong beras merah dan hitam diharapkan juga dapat terikat sehingga menghasilkan snack bar yang kompak.

Snack bar beras warna dengan variasi jenis beras warna kemudian dinilai tingkat kesukaan meliputi warna, rasa, tekstur, dan aroma diperoleh dengan uji 5 skala hedonik (1=Sangat Tidak Suka, 2=Tidak Suka, 3=Netral, 4=Suka, 5=Sangat Suka),pada panelis agak terlatih yaitu 25 orang mahasiswa Program Studi Ilmu Gizi Fakultas Kedokteran Universitas Diponegoro Semarang. Hasil penelitian pendahuluan menunjukkan snack bar dengan perbandingan bahan pengikat dan bahan pengisi yaitu 1 : 1,2 adalah yang paling disukai oleh panelis sehingga digunakan sebagai formulasi tetap pada penelitian utama. Hasil analisis penelitian pendahuluan dapat dilihat pada Lampiran 2. Setiap formulasi pada penelitian utama dilakukan pengujian kandungan zat gizi scara duplo, protein, lemak, karbohidrat, natrium, kalium, fosfor dan antioksidan pangan sebanyak tiga kali pengulangan, serta penilaian tingkat kesukaan snack bar dilakukan satu kali tanpa pengulangan.

Pembuatan snack bar pada penelitian ini menggunakan bahan utama berupa brondong beras warna meliputi brondong beras coklat, merah dan hitam. Kemudian dilakukan pelelehan bahan pengikat, pencampuran dan pencetakan bahan pengikat serta bahan pengisi. Proses pembuatan snack bar dapat dilihat pada Lampiran 2. 
Brondong beras coklat, merah yang digunakan untuk pembuatan snack bar diproduks oleh industri brondong beras rumahan Pak Kus, Tegal Rejo, Ambarawa yang diolah dengan ekstruksi (puffing gun) dengan bahan baku butiran beras coklat dan merah diproduksi oleh PB Mahkota ABC Tangerang serta beras hitam diproduksi oleh Merbabu Salatiga. Bahan pengikat menggunakan pemanis buatan berupa inulin dengan merk Orafti ${ }^{\circledR}$ GR dan isomalt dengan merk Platinit $\mathrm{GmbH}$, minyak kelapa dengan merk Barco diproduksi oleh PT. Barco, susu Nephrisol diproduksi oleh PT Kalbe Farma Tbk, serta CMC.

Data yang dikumpulkan pada penelitian utama adalah variabel terikat meliputi kandungan zat gizi makro dan mikro snack bar beras warna. Kandungan zat gizi yang dianalisis meliputi kadar protein yang diperoleh dengan metode kjeldahl $(\mathrm{g}),{ }^{20}$ lemak diperoleh dengan metode soxhlet $(\mathrm{g}),{ }^{20}$ karbohidrat diperoleh dengan metode by difference $(\mathrm{g}){ }^{20}$ energi diperoleh dengan menjumlahkan kadar protein, lemak, dan karbohidrat (kkal), natrium dan kalium diperoleh dengan alat Spektroskopi Serapan Atom (SSA) (mg) ${ }^{20}$ fosfor diperoleh dengan metode kalorimeter (MolibdatVanadat) (mg), ${ }^{20}$ aktivitas antioksidan pangan diperoleh dengan metode DPPH (2,2 dhipenyl - 1pycrilhidrazyil) (\%).

\section{HASIL}

\section{Kandungan Zat Gizi Snack Bar}

Hasil analisis kandungan zat gizi makro dan mikro serta aktivitas antioksidan snack bar dapat dilihat pada Lampiran 5 dan secara singkat pada Tabel 1 dan Tabel 2.

Table 1. Hasil Analisis Kandungan Zat Gizi Makro Per 100 Gram Snack Bar

\begin{tabular}{ccccc}
\hline \multirow{2}{*}{$\begin{array}{c}\text { Formula Snack } \\
\text { Bar }\end{array}$} & $\begin{array}{c}\text { Protein } \\
(\mathbf{g})\end{array}$ & $\begin{array}{c}\text { Lemak } \\
(\mathbf{g})\end{array}$ & $\begin{array}{c}\text { Karbohidrat } \\
(\mathbf{g})\end{array}$ & $\begin{array}{c}\text { Energi } \\
(\mathbf{k k a l})\end{array}$ \\
\hline Beras coklat & $6,95 \pm 0,43$ & $3,63 \pm 0,02^{\mathrm{a}}$ & $85,11 \pm 1,22$ & $400,98 \pm 5,09$ \\
Beras merah & $6,32 \pm 0,44$ & $3,79 \pm 0,03^{\mathrm{b}}$ & $84,21 \pm 0,10$ & $396,17 \pm 1,6$ \\
Beras hitam & $6,59 \pm 0,61$ & $3,24 \pm 0,10^{\mathrm{c}}$ & $84,33 \pm 0,78$ & $392,84 \pm 1,40$ \\
& $\mathrm{p}=0,356$ & $\mathrm{p}=0,000$ & $\mathrm{p}=0,416$ & $\mathrm{p}=0,054$ \\
\hline
\end{tabular}

Keterangan: Angka yang diikuti dengan huruf superscript berbeda (a, b, c) menunjukkan perbedaan yang bermakna

Table 2. Hasil Analisis Kandungan Zat Gizi Mikro Per 100 Gram Snack Bar

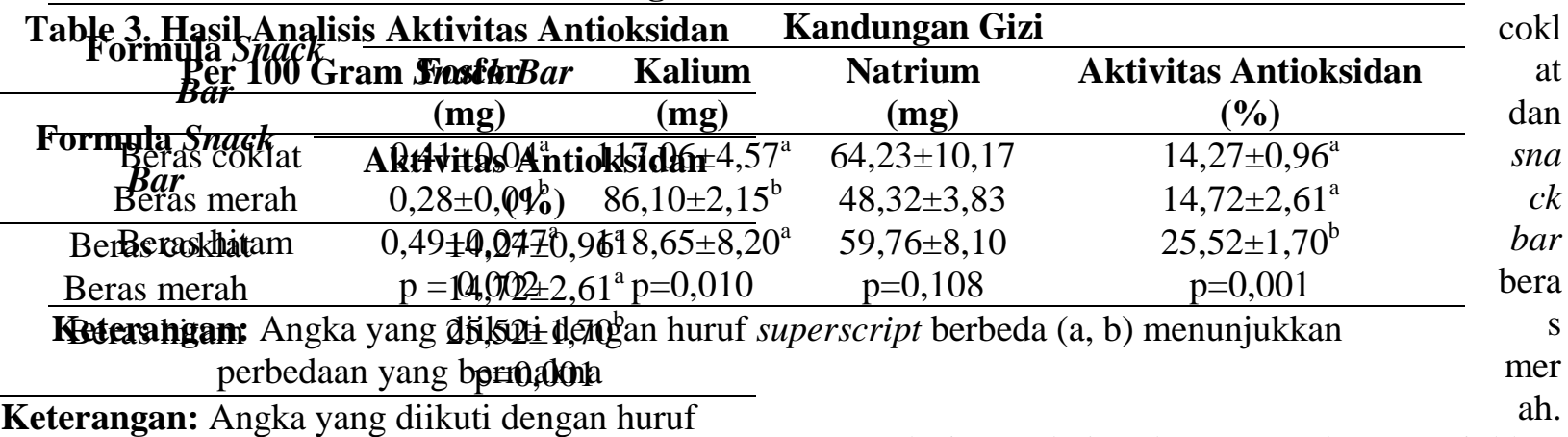

superscript berbeda (a, b)

menunjukkan perbedaan yang

bermakna

Hasil analisis menunjukkan tidak terdapat perbedaan bermakna antar formulasi pada kandungan protein, karbohidrat, energi, dan natrium. Kemudian terdapat perbedaan kandungan lemak bermakna pada snack bar beras coklat, merah dan hitam. Formulasi snack bar beras hitam menunjukkan perbedaan kandungan antioksidan yang bermakna dengan formulasi snack bar beras
Formulasi snack bar beras merah menunjukkan perbedaan kandungan kalium dan fosfor yang bermakna dengan formulasi snack bar beras coklat dan snack bar beras hitam.

\section{PEMBAHASAN}

1. Kandungan Zat Gizi Snack Bar

Nefropati diabetik merupakan salah satu komplikasi mikrovaskuler akibat hiperglikemi yang bersifat kronis. Pasien nefropati diabetik yang dapat berkembang menjadi penyakit ginjal stadium akhir adalah $40 \%$ dari seluruh pasien. ${ }^{1,2}$ Strategi yang 
dapat dilakukan untuk menurunkan risiko atau memperlambat progresifitas nefropati diabetik adalah dengan melakukan penatalaksanaan diet yang tepat untuk mempertahankan status gizi optimal, mengendalikan glukosa darah, lipida darah, tekanan darah, dan asupan protein, serta mempertahankan elektrolit. ${ }^{3}$ Selain itu untuk mengurangi efek radikal bebas pada penderita nefropati diabetik diperlukan asupan antioksidan seperti senyawa fenolik yang berfungsi sebagai antioksidan. ${ }^{4}$ Hal ini didukung oleh hasil penelitian yang menyebutkan bahwa antioksidan mampu mengendalikan kadar glukosa darah dan mencegah komplikasi diabetes mellitus. ${ }^{12}$

Asupan protein dalam penatalaksaan diet pada penderita nefropati diabetik perlu diperhatikan. Pembatasan asupan protein perlu dilakukan berkaitan dengan penurunan fungsi ginjal pada penderita nefropati diabetik. Kandungan protein untuk makanan selingan pasien nefropati dibetik berdasarkan perhitungan kebutuhan protein $10 \%$ dalam makanan selingan diperoleh $5 \mathrm{~g} / \mathrm{sajian}$. Berat satu batang snack bar diketahui berkisar 16$20 \mathrm{~g}$ sehingga satu takaran saji dapat mengonsumsi 2-3 batang snack bar. Kadar protein dalam satu takaran saji sesuai dengan perhitungan kebutuhan protein dalam makanan selingan yaitu berkisar 2,53-2,78 $\mathrm{g} / 40 \mathrm{~g} /$ sajian. Diet protein rendah pada pasien nefropati diabetik berperan mengurangi risiko penurunan fungsi ginjal yaitu dengan mengurangi beban asam amino yang melewati glomerulus sehingga mengurangi risiko terjadinya kerusakan sel epitel dan proteinuria,

Kandungan lemak untuk makanan selingan pasien nefropati dibetik berdasarkan perhitungan kebutuhan lemak $10 \%$ dalam makanan selingan diperoleh 6,7 g/sajian. Berdasarkan hasil penelitian, kadar lemak satu takaran saji snack bar berkisar 1,3-1,51 $\mathrm{g} / 40 \mathrm{~g} / \mathrm{sajian}$.

Kandungan karbohidrat untuk makanan selingan pasien nefropati dibetik berdasarkan perhitungan kebutuhan karbohidrat 10\% dalam makanan selingan diperoleh 30 $\mathrm{g} / \mathrm{sajian}$. Berdasarkan hasil penelitian, kadar karbohidrat dalam satu takaran saji snack bar berkisar 33,68-34,04 g/40 g/sajian. Tingginya kadar tersebut dapat disebabkan oleh kandungan mula-mula setiap jenis brondong beras yang tinggi serta adanya penambahan bahan pengikat yaitu isomalt dan inulin.

Karbohidrat berperan dalam penentuan karakteristik makanan seperti isomalt dan inulin yang menimbulkan rasa manis dan terjadi reaksi pencoklatan non enzimatis (maillard) antara gula pereduksi dan asam amino yang menghasilkan warna coklat dan aroma caramel pada produk. ${ }^{21}$

Kandungan energi untuk makanan selingan pasien nefropati dibetik berdasarkan perhitungan kebutuhan energi $10 \%$ dalam makanan selingan diperoleh $200 \mathrm{kkal} / \mathrm{sajian}$. Hasil penelitian menunjukkan kandungan energi dalam satu takaran saji snack bar berkisar 157,14-160,39 kkal/40 g/sajian.

Pemenuhan asupan protein, lemak dan karbohidrat yang cukup, penting untuk membantu menyediakan energi dalam menjalankan setiap aktifitas, mempertahankan berat badan yang sesuai serta menjaga penggunaan protein untuk pembentukan dan perbaikan jaringan tubuh sehingga dapat meminimalkan hasil sisa metabolisme protein yang dapat memperberat kerja ginjal pasien. $^{22,23}$

Kandungan fosfor untuk makanan selingan pasien nefropati dibetik berdasarkan perhitungan kebutuhan fosfor $10 \%$ dalam makanan selingan diperoleh $170 \mathrm{mg} / \mathrm{sajian}$. Berdasarkan hasil penelitian, kadar fosfor dalam satu takaran saji snack bar sudah memenuhi standar tersebut, yaitu berkisar 0,113-0,190 mg/40 g/sajian. Pembatasan asupan fosfor berperan dalam membantu menurunkan kadar fosfor dalam tubuh serta mencegah terjadinya hiperfosfatemia (kadar fosfat dalam darah $>6 \mathrm{mg} / \mathrm{dl}) .{ }^{16}$

Kadar fosfor snack bar yang rendah dipengaruhi oleh adanya penambahan bahan pengikat yaitu inulin. Inulin merupakan salah satu bentuk functional fiber yang terdiri atas polimer-polimer fruktosa yang terkandung dalam bahan makanan. ${ }^{24}$ Inulin memiliki sifat daya ikat yang baik sehingga pemberiannya dalam formulasi snack bar dapat digunakan sebagai pengganti gula, lemak dan bahan pengental. Inulin dapat mengikat air dan memiliki rasa serta warna netral sehingga dapat memodifikasi tekstur unik pada produk snack bar. $^{25}$ Penelitian menunjukkan konsumsi inulin dan oligisakarida dapat mengurangi terjadinya uremia dan meningkatkan ekskresi nitrogen melalui feses 
sehingga dapat membantu menurunkan progresifitas nefropti diabetik. ${ }^{26}$ Penelitian menunjukkan konsumsi oligofruktosa 15 gram/hari selama 15 hari dan dilanjutkan dengan inulin 15 gram/hari pada 15 hari berikutnya dapat meningkatkan ekskresi nitrogen melalui feses pada orang sehat. ${ }^{27}$ FDA menyebutkan bahwa konsumsi inulin 10 gram/hari dinyatakan aman dalam Generally Recognized as Safe (GRAS). ${ }^{28}$

Kandungan kalium untuk makanan selingan pasien nefropati dibetik berdasarkan perhitungan kebutuhan kalium 10\% dalam makanan selingan diperoleh $400 \mathrm{mg} / \mathrm{sajian}$. Berdasarkan hasil penelitian, kandungan kalium dalam satu takaran saji snack bar sudah memenuhi standar tersebut, yaitu berkisar 34,44-47,46 mg/40 g/sajian.

Kandungan natrium untuk makanan selingan pasien nefropati dibetik berdasarkan perhitungan kebutuhan natrium $10 \%$ dalam makanan selingan diperoleh $230 \mathrm{mg} / \mathrm{sajian}$. Berdasarkan hasil penelitian, kandungan natrium dalam satu takaran saji snack bar sudah memenuhi standar tersebut, yaitu berkisar 19,33-25,69 mg/40 g/sajian.

Asupan antioksidan perlu diperhatikan untuk mengurangi risiko progresifitas nefropati diabetik. Penderita nefropati diabetik mengalami gangguan stress oksidatif yang terjadi akibat ketidakseimbangan antara pembentukan radikal bebas dan kemampuan antioksidan alami dari tubuh. Stres oksidatif berkaitan dengan inflamasi sistemik, disfungsi endotel, gangguan sekresi sel $\beta$ pankreas dan gangguan utilitas glukosa pada jaringan perifer. ${ }^{12}$ Berdasarkan hasil penelitian aktivitas antioksidan dalam satu takaran saji snack bar berkisar 14,27-25,52 \%/40 g/sajian. Snack bar dengan aktivitas antioksidan tersebut, diharapkan dapat menurunkan risiko stress oksidatif pada penderita nefropati diabetik.

\section{Rekomendasi Snack Bar}

Snack bar beras warna dapat direkomendasikan sebagai salah satu alternatif makanan selingan untuk pasien nefropati diabetik karena formulasi tersebut memiliki kandungan zat gizi sesuai dengan perhitungan $10 \%$ dari kebutuhan zat gizi dalam sehari pasien nefropati diabetik. Rekapitulasi kandungan zat gizi snack bar beras warna/40 g/sajian dapat dilihat pada Tabel 3.

\section{SIMPULAN DAN SARAN}

\section{Simpulan}

1. Semua snack bar beras warna memiliki kandungan protein dan lemak yang rendah namun kandungan karbohidrat lebih tinggi bila dibandingkan hasil perhitungan kandungan zat gizi makanan selingan pasien nefropati diabetik.

2. Snack bar beras hitam memiliki aktivitas antioksidan (25,52\% per $100 \mathrm{~g}$ snack bar) yang paling tinggi diantara ketiga jenis snack bar.

\section{Saran}

1. Snack bar yang direkomendasikan adalah snack bar beras hitam yang memiliki kandungan protein 2,63 g, lemak 1,30 g, karbohidrat 33,73 g, energi 157,14 kkal, serat 0,56 g, aktivitas antioksidan 14,27-25,52 \%, kalium $47,46 \mathrm{mg}$, natrium $23,90 \mathrm{mg}$, fosfor $0,19 \mathrm{mg}$ dalam berat takaran saji $40 \mathrm{~g}$.

2. Diperlukan penambahan lipid untuk meningkatan kandungan energi snack bar beras warna tanpa meningkatkan kandungan proteinnya.

3. Diperlukan penelitian lebih lanjut mengenai pengaruh snack bar beras warna terhadap pasien nefropati diabetik secara langsung.

\section{UCAPAN TERIMA KASIH}

Penulis mengucapkan terima kasih kepada mahasiswa Program Studi Ilmu Gizi Fakultas Kedokteran Universitas Diponegoro Semarang yang telah berkenan menjadi panelis uji tingkat kesukaan snack bar beras warna.

\section{DAFTAR PUSTAKA}

1. Campbell RK, Martin TM. The cronic Burden of Diabetes. American Journal of Managemen Care 2009: 15 52:48-S254.

2. International Diabetes Federation (IDF). One adult in ten will have diabetes by $2030.5^{\text {th }}$ edition Diabetes Atlas, 2011.

3. Tjokropawiro A. Capita selecta in endocrinology and metabolism. Proceedings of the $23^{\text {th }}$ National Congress PKB; 2008, Surabaya, Indonesia

4. Johansen JS, Harris AK, Rychly DJ, Ergul A. Oxidative stress and the use of antioxidants in diabetes linking basic science to clinical practice. Cardiovasc Diabet. 2005 April 29: 4(5)

5. American Diabetes Association (ADA): Standards of medical care in diabetes mellitus, Diabetic Care 34 (Suppl 1):S11, 2011.

6. Chan L, Therashima T, Fujimiya M, Kojima H. Chronic diabetic complication the body's adaptive 
response to hyperglycemia gone awry. Trans An Climatol Assoc 2006: 117:341-352.

7. Yawadio, R., Tanimori, S. dan Morita, N. Identification of phenolic compounds isolated from pigmented rices and their aldose reductase inhibitory activities. J Food Chem. 2007; 101: 1616-1625.

8. American Diabetes Association (ADA): Nutrition recommendation and interventions for diabetes. In: Mahan LK, Escott-Stump S, Raymond JL. Krause's Food Nutrition, and Diet Therapy $13^{\text {th }}$ Edition Philadelphia: WB Saunders Company; 2012. p. 705

9. Pan Y, Guo LL Jin HM. Low-protein diet for diabetic nephropathy: a meta-analysis of randomized controlled trials. Am J Clin Nutr. 2008;88: 660-6.

10. Darmarini, D. Kresnawati T. Penatalaksanaan diet pada nefropati diabetik. 2004, 27(2):77-81

11. Snetselaar LG. Nutrition counseling skills for the nutrition care process $4^{\text {th }}$ ed. USA: Jones and Bartlett; 2009. Chapter 7, Nutrition counseling in treatment of renal disease; p.339

12. Franz MJ, et al: American Diabetes Association pocket guide to lipid disorder, hypertension, diabetes, and weight management, Chicago, II, 2010, American Diabetes Association.

13. Ginmey MJ, Lanham-New Susan A, Cassidy Aedin, Vorster Hester $\mathrm{H}$, editor. Introduction to human nutrition $2^{\text {nd }}$ ed. USA : A John Wiley \& Sons, Ltd. 2009.p.212

14. Mahmud Mien K, Zulfianto Nils Aria, editor. Tabel komposisi pangan Indonesia. Jakarta; PT Elex Media Komputindo; 2009. p. 24-26

15. Wilkens, Katy G, Juneja, Veena. Medical nutrition therapy for renal disorder. In: Mahan L. Kathleen and Escott-Stump Sylvia Krause's food and nutrition therapy. $12^{\text {th }}$ ed. Canada: Saunders; 2008. p. $922-923 ; 928$.

16. NKF KDOQI Clinical Practice Guidelines and Clinical Practice Recommendation for Diabetes and Chronic Kidney Disease. Am J Kidney Dis. 2007;49:S1=SI80.

17. Hanhineva $\mathrm{K}$, Torronen $\mathrm{R}$, Bondia-Pons I, Pekkinen J, Kolehmainen M, Mykkanen $\mathrm{H}$, Poutanen K, Impact of dietary polyphenols on carbohydrate metabolism. Int J Mol Sci 2010; 11 : 1365-402.

18. Wedick, NM. Dietary flavonoid intakes and risk of type 2 diabetes in US men and woman. Am J Clin Nutr 2012; 95:925-33.

19. Yodmanee, S., Karrila, T.T. and Pakdeechanuan, P. Physical, chemical and antioxidant properties of pigmented rice grown in Southern Thailand. International Food Research Journal. 2011; 18(3): 901-906.

20. Andarwulan Nuri, Kusnandar Feri, Herawati Dian. Analisis pangan. Jakarta: Dian Rakyat; 2011.p.9698, 123-125,155, 193-194.
21. Muchtadi Tien R, Ayustaningwarno Fitriyono. Teknologi proses pengolahan pangan. Bandung: Alfabeta 2010.

22. Wilkens Katy G, Juneja Veena. Medical nutrition therapy for renal disorders. In: Mahan L. Kathleen and Escott-Stump Sylvia. Krause's food and nutrition therapy. 12th ed. Canada: Saunders; 2008. p. 922-923; 928.

23. National Kidney Foundation. Nutrition and chronic kidney disease (stages 1-4): Are you getting what you need?. New York: National Kidney Foundation Inc 2010.

24. Wilkens Katy G, Juneja Veena. Medical nutrition therapy for renal disorders. In: Mahan L. Kathleen and Escott-Stump Sylvia. Krause's food and nutrition therapy. 12th ed. Canada: Saunders; 2008. p. 922-923; 928.

25. Cordina, GG, Bilan E. Using inulin bakery product. Journal of Agroalimentary Proceses and Technologies. 2006; 1:255-230..

26. Kaur Narinder, Gupta Anil K. Applications of inulin and oligofructose in health and nutrition. J.Biosci 2002; 27. 703-714.

27. Kolida S, Tuohy K, Gibson G.R. Prebiotic effects of inulin and oligofructose. British Journal of Nutrition 2002; 87, Suppl. 2, S193-S197.

28. ENVIRON Intestinal Coorporation. Generally Recognized as safe (GRAS) Notification for Fruta. Virginia. 2002 